\title{
THE INTERACTION BETWEEN RELIGIOUS FREEDOM, EQUALITY AND HUMAN DIGNITY
}

\author{
Prof Gerrit Pienaar \\ Faculty of Law; University of Potchefstroom
}

\begin{abstract}
In balancing religious freedom with the right to equality and human dignity of persons affected by discriminatory measures, the provisions of sections 9, 10, 15(1), 31(1) and 36 of the Constitution of the Republic of South Africa Act 108 of 1996 and sections 7, 8 and 14 of the Promotion of Equality and Prevention of Unfair Discrimination Act 4 of 2000 have to be considered. Especially in the case of racial or gender discrimination, the burden rests on the respondent to prove that the distinction is based on acknowledged church dogma or religious belief, and is of such a nature that it passes the test of a nuanced and context-sensitive form of balancing of these freedoms and the right to human dignity and equality of persons affected by them.
\end{abstract}

\section{BACKGROUND}

Religious freedom (s 15(1)) and freedom of religious communities (s 31(1)), like most of the fundamental rights entrenched in the Constitution of the Republic of South Africa 108 of 1996, are not applied in isolation. In this introduction I want to concentrate on the interaction between religious freedom and the constitutional values of equality and human dignity. This interaction illustrates the complexity of the church-state relationship, and especially the pitfalls of a strict separation between church and state on the one hand, or a cosy relationship between the state and state supported institutions on the other hand. ${ }^{1}$

1 De Waal, J, Currie, I \& Erasmus, G 2000. The Bill of Rights Handbook, 263. 


\section{CONSTITUTIONAL PROVISIONS}

Freedom of belief or religion in terms of section 15(1) of the Constitution is a manifestation of the constitutional principle that everyone has the right to decide in what way he/she wants to express his/her belief and take part in religious practices. This aspect is connected to the fact that individuals have the right to decide where they want to commit themselves in the free exercise of their religious convictions as protected by section 31(1). It leads to a free society in which every individual can develop and realise him-/herself. ${ }^{2}$ Section 9 prohibits any discrimination against a person on the ground of race, gender, sex, pregnancy, marital status, ethnic or social origin, colour, sexual orientation, age, disability, belief, conviction, culture or language (section 9(4)), with the exception of cases where such discrimination can be justified (section 9(5)).

Freedom and equality as principles to be taken into account in this regard seem to be contradictory principles. ${ }^{3}$ It is, however, necessary that a balancing of interests should take place, which will indicate in every specific case to what extent the equality principle is compatible with the freedom of religion of individuals. ${ }^{4}$ In balancing these interests the degree to which an association or institution is of a private or public nature and/or functions accordingly is important, but not decisive. ${ }^{5}$

In $S$ v Manamela and Another ${ }^{6}$ the balancing effect of section 36 was described as an overall assesment that will vary from case to case:

In essence, the Court must engage in a balancing exercise and arrive at a global judgment on proportionality and not adhere mechanically to a sequential check-list. As a general rule, the more serious the impact of the measure on the right, the more persuasive or compelling the

$2 S$ v Lawrence; S v Negal; S v Solberg 19974 SA 1176 (CC) par 92; Woolman \& De Waal 1994, 340. See in this regard the distinction between the individual and collective elements of religion by Rautenbach, I M \& Malherbe, E F J 1999. Staatsreg, 375 and Malherbe, E F J 1998. Die grondwetlike beskerming van godsdiensvryheid TSAR, 680.

3 Davis, D 1994. Equality and equal protection in Van Wyk D et al (eds) Rights and constitutionalism, 196; Woolman \& De Waal 1994, 340-341.

4 Davis 1994, 196: "Equality thus is inextricably linked to the conception of liberty if society is to allow the promotion of competeting interests. Where equality is different, however, to liberty is that it depends upon a comparator. It is here that equality becomes an enigmatic concept." See also S v Manamela and Another 20003 SA 1 (CC).

5 Rautenbach, I M 1995. General provisions of the South African Bill of Rights, 77-78; Strydom, HA 1995. The private domain and the bill of rights SAPL, 52-68.

620003 SA (CC) 1 at par 32 and 33. 
justification must be. Ultimately, the question is one of degree to be assessed in the concrete legislative and social setting of the measure, paying due regard to the means which are realistically available in our country at this stage, but without losing sight of the ultimate values to be protected....

Each particular infringement of a right has different implications in an open and democratic society based on dignity, equality and freedom. There can accordingly be no absolute standard for determining reasonableness.

\section{EQUALITY LEGISLATION}

The equality principle in terms of section 9 of the Constitution was further strengthened by the promulgation of the Promotion of Equality and Prevention of Unfair Discrimination Act 4 of 2000. In the preamble it is stated that the consolidation of democracy in South Africa requires the eradication of social and economic inequalities. Systemic inequalities and unfair discrimination remain deeply embedded in social structures, practices and attitudes. The Act endeavours to facilitate the transition to a democratic society, united in its diversity, marked by human relations that are caring and compassionate, and guided by the principles of equality, fairness, equity, social progress, justice, human dignity and freedom.

Chapter 4 prescribes the procedure of instituting a claim in terms of the Act. An important issue is the determination of the burden of proof and whether the discrimination was fair or unfair. In terms of section 13(1) the complainant may make out a prima facie case of discrimination, whereupon the respondent must prove, on the facts before the court, that the discrimination did not take place as alleged or the conduct is not based on one or more of the prohibited grounds. If the respondent does not succeed in rebutting that the discrimination took place on any of the specific prohibited grounds ${ }^{7}$, such discrimination is unfair, unless the respondent proves that the discrimination is fair (section 13(2)(a)). This procedure differs from the normal procedure set by Harksen $v$ Lane $N \mathrm{O}^{8}$ where the applicant has to prove that discrimination on any of the grounds prohibited in section 9 of the Constitution took place, whereupon the presumption of

7 See the grounds listed in (a) of the description of 'prohibited grounds' in s 1 of the Act, which correspond with the grounds of s 9(3) of the Constitution. 
unfair discrimination may be rebutted by the respondent. Where the discrimination is based on any other ground that causes or perpetuates systemic disadvantage, undermines human dignity or adversely affects the equal enjoyment of a person's rights and freedoms in a serious manner, ${ }^{9}$ section $13(2)(b)$ stipulates that such discrimination is unfair, unless the respondent proves that it is fair.

Sections 14 states certain factors that have to be used in the determination of the fairness or unfairness of discriminatory actions or procedure. These factors are an expansion of the factors stated in section 36(1) of the Constitution:

(i) It is not unfair to take measures designed to protect or advance persons previously disadvantaged by unfair discrimination.

(ii) In determining whether discrimination is fair, the context and the question whether the discrimination reasonably and justifiably differentiates between persons according to objectively determinable criteria, intrinsic to the activity concerned, should be considered.

(iii) Whether the discrimination impairs human dignity.

(iv) The impact of the discrimination on the complainant.

(v) The position of the complainant in society and whether he/she suffers from patterns of disadvantage.

(vi) The nature and extent of the discrimination.

(vii) Whether the discrimination is systemic in nature.

(viii) Whether the discrimination has a legitimate purpose.

(ix) Whether the discrimination achieves its purpose and whether there are less restrictive and diasadvantageous means to achieve the purpose.

(x) Whether and to what extent the respondent has taken such steps as being reasonable in the circumstances to address the disadvantage and accommodate diversity.

\section{EQUALITY AND DISCRIMINATION IN CASE LAW}

19981 SA 300 (CC) 324H-325D; Kok 2001, 304.

9 See (b) of the description of prohibited grounds in s 1 of the Act. These grounds are not stated in s 9 of the Constitution. 
From the above-mentioned discussion it is clear that freedom of religion is not protected and applied in isolation, but all the rights, freedoms and values of the Bill of Rights are applied in a balanced way in the context and according to the circumstances of a specific case. Therefore the right to equality and non-discrimination always forms part of the balancing process.

\subsection{Christian Education South Africa v Minister of Education ${ }^{10}$}

An interesting application of the constitutional principles regarding freedom of religion, belief and opinion in terms of section 15(1) of the Constitution is the decision of the constitutional court in Christian Education South Africa v Minister of Education. The purpose of the application brought by Christian Education South Africa, a voluntary association representing 196 independent Christian schools with a total of approximately 14500 pupils, was to obtain an order declaring section 10 of the South African Schools Act 84 of 1996, which prohibits corporal punishment in schools, invalid and unconstitutional in that it interferes with their right to freedom of religion and cultural life. The Association contended that corporal punishment is a vital aspect of Christian religion and that it is applied in the light of its Biblical context using Biblical guidelines that impose a responsibility on parents for the training of their children. Any limitation on this freedom is based on religious discrimination and, therefore, on the constitutional value of equality. The defence of the Minister of Ecucation was that it is not the prohibition, but the infliction of corporal punishment, that infringes the constitutional rights of equality (section 9) and human dignity (section 10). The court accepted that the freedom of religion (section 15(1)) and the freedom to practise religion in terms of section 31(1)(a) are to a certain extent interlinked. Although section 15(1) protects individual beliefs and religious practices, it cannot be separated from the proviso of section 31(2) altogether: ${ }^{11}$

Section 31(2) ensures that the concept of rights of members of communities that associate on the basis of language, culture and

1020004 SA 757 (CC). See the discussion of the a quo case 19991 BCLR 951 (SE) by Du Plessis, M 2000. Doing damage to freedom of religion SLR 295-305.

11 774A-C. S 31(2) states: "The rights in subsection (1) may not be exercised in a manner inconsistent with any provision of the Bill of Rights." 
religion, cannot be used to shield practices which offend the Bill of Rights. These explicit qualifications may be seen as serving a double purpose. The first is to prevent protected associational rights of members of communities from being used to 'privatise' constitutionally offensive group practices and thereby immunise them from external legislative regulation or judicial control. This would be particularly important in relation to practices previously associated with the abuse of the notion of pluralism to achieve exclusivity, privilege and domination. The second relates to oppressive features of internal relationships primarily within the communities concerned, where section 8 , which regulates the horizontal application of the Bill of Rights, might be specially relevant.

This is clearly an area where interpretation should be prudently undertaken so that appropriate constitutional analysis can be developed over time in the light of the multitude of different situations that will arise.

The last-mentioned caution is extremely important. It is still unclear to what extent the state (by way of legislation or constitutional case law) will give precedence to the equality clause in especially racial and gender discrimination issues. ${ }^{12}$ Will the strict scrutiny-test or the context sensitive balancing-test be applied by courts?

The fact that churches and religious institutions function mainly in the private sphere may be a limiting factor on state intervention. Woolman and De Waal ${ }^{13}$ state as follows:

Cultural (and religious) associations will generally find themselves in a similarly advantageous position. To the extent that these associations stick to bona fide religious and cultural activities they will be relatively immune to state intervention.

While there may be the odd good reason to open up the membership policies of cultural and religious associations, there are no good reason for state interference in the internal affairs of such associations. The internal affairs of such associations are generally linked to some concrete vision of religious or community life. In a liberal society the state should have no role to play in the construction of these particular visions of the good life.

Although the viewpoint of these authors can be approved of in broad outline, the state ought to be able to intervene in the internal relationships or activities of the organisation if discriminating measures of a church are not applied on the basis of religious

12 See Brink v Kitshoff 19966 BCLR 752 (CC); Carpenter, G. 2001. Equality and non-discrimination in the new South African constitutional order. THRHR 64(3) 409419.

$131994,384$. 
considerations. Furthermore, in the application of the equality and non-discrimination principles, especially regarding race and gender, the fairness of the discrimination should be measured according to the factors stated in section 14(3) of the Promotion of Equality Act, and especially to what extent human dignity is thereby impaired and what the impact of the discrimination is on the complainant. On the question whether a strict scrutiny test of state intervention should be applied in the case of equality and discrimination matters, the court held in the Christian Education case that in the case of the limitation of religious freedom a nuanced and context-sensitive form of balancing will be more suitable for the application of section 36 of the Constitution (and by implication section 14(3) of the Promotion of Equality Act) than the American strict scrutiny test. ${ }^{14}$

The unanimous decision of the constitutional court in the Christian Education case was primarily based on effectuating equality through the balancing effect of the constitutional value of the protection of human dignity. It was acknowledged that a multiplicity of intersecting constitutional values and interests were involved, some overlapping and some competing: ${ }^{15}$

The overlap and tension between the difficult clusters of rights reflects themselves in contradictory assessments of how the central constitutional value of dignity is implacated. On the one hand, the dignity of the parents may be negatively affected when the State tells them how to bring up and discipline their children and limits the manner in which they may express their religious beliefs. The child who has grown up in the particular faith may regard the punishment, although hurtful, as designed to strengthen his character. On the other hand, the child is being subjected to what an outsider might regard as the indignity of suffering a painful and humiliating hiding deliberately inflicted on him in an institutional setting. Indeed, it would be unusual if the child did not have ambivalent emotions. It is in this complex factual and psychological setting that the matter must be decided.

14 Christian Education par 29 and 30. See also Rautenbach 2001, 331-332. But see Brink v Kitshoff par 40-42 and Carpenter 2001, 419 on the necessity of strict scrutiny in the case of racial and gender discrimination. However, it is important to note that racial or gender discrimination did not form part of the issues under consideration in the Christian Education-case.

15 Par 15 768E-769C. 
In applying the proportionality principle to the different aspects of the constitutional value of human dignity, justice Sachs held that the ban on corporal punishment formed part of a legislative scheme designed to establish uniform educational standards. Although such measure may be considered as discriminatory on religious grounds, the ban was part of a comprehensive process of eliminating state-sanctioned use of physical force as a method of punishment: ${ }^{16}$

The outlawing of physical punishment in the school accordingly represented more than a pragmatic attempt to deal with disciplinary problems in a new way. It had a principled and symbolic function, manifestly intended to prmote respect for the dignity and physical and emotional integrity of all children.

\section{A. $\quad$ Prince $v$ President, Cape Law Society ${ }^{17}$}

The question before the constitutional court was whether the respondent might refuse the membership application of an acknowledged Rastafarian who was convicted in terms of the Drugs and Drug Trafficking Act 140 of 1992 of smoking cannabis as part of his religious observances. In judging the applicant's evidence regarding the religious practices of the Rastafari, the court referred to the Christian Education case ${ }^{18}$ in stressing the importance of the right to freedom of religion, belief and opinion in an open and democratic society. The constitutional court again confirmed that a person's freedom, and in this case a person's religious freedom, is one of the key ingredients of his/her dignity. ${ }^{19}$ Yet freedom of religion goes beyond protecting the inviolability of the individual conscience, but also includes a person's religious activities. ${ }^{20}$ However, this

16 786B-C.

1720022 SA 794 (CC).

18 815F-816A. In the Christian Education case it was held that section 15(1) safeguards private religious beliefs and practices, which will not necessarily be upheld in the application of the limitation clause (s 36 ) to the practices of religious communities in terms of section 31(1), and was indeed not upheld in the case of Christian schools.

19 816C-D: "The protection of diversity is the hallmark of a free and open society. It is the recognition of the inherent dignity of all human beings. Freedom is an indispensable ingredient of human dignity. Human dignity is an important constitutional value that not only informs the interpretation of most, if not all, other constitutional rights, but is also central in the limiatations analysis."

20 Christian Education case 772G-773D: "There are a number of other provisions designed to protect the rights of members of communities. They underline the constitutional value of acknowledging diversity and pluralism in our society and give a particular texture to the broadly phrased right to freedom of association contained in s 18. Taken together, they affirm the right of people to be who they are without being forced to subordinate themselves to the cultural and religious norms of others, 
right to personal belief and religious practices in terms of section 15(1) and the right to practice these beliefs in a community in terms of section 31(1), are in the first instance subjected to the limitation embodied in section 31(2) and in the second instance to the limitation clause of section 36 (as expanded by the factors stated in section 14(3) of the Promotion of Equality Act). In the proportionality analysis required by section 36 on the Constitution, the majority of the court (justices Chaskalson, Ackermann, Kriegler, Goldstone and Yacoob), rejected the notion that the practice of religion, as distinct from belief, is absolute. The majority contended that, in dealing with the limitation of rights, "...the Constitution does not call for different levels of scrutiny, but expressly contemplates the use of a nuanced and context-sensitive form of balancing in the s 36 proportionality analysis." ${ }^{21}$ Therefore they found that the state's interest in limiting the use of harmful drugs (in this case the possession of cannabis) in the interest of the public at large and to honour international obligations exceeds the religious freedom of Rastafari to use cannabis in the exercise of religious practices. ${ }^{22}$

\section{CONCLUSION}

Although the interaction between freedom of religion and the equality principle protects a person from unnecessary state intervention in his/her religious activities, these rights are not absolute or unlimited. In the case of discrimination based on a prohibition on the exercise of religious practices, the burden rests on the respondent to proof that a distinction is based on acknowledged church dogma or religious beliefs, and is of such a nature that it passes the test of a nuanced and context-sensitive form of balancing of these rights and the right to equality of affected persons. It was even proposed that a

and highlight the importance of individuals and communities being able to enjoy what has been called the 'right to be different'. In each case, space has been found for members of communities to depart from a legal norm. These provisions collectively and separately acknowledge the rich tapestry constituted by civil society, indicating in particular that language, culture and religion constitute a strong weave in the overall pattern.

It might well be that in the envisaged pluralistic society members of large groups can more easily rely on the legislative process than can those belonging to smaller ones, so that the latter might be specially reliant on constitutional protection, particularly if they express their beliefs in a way that the majority regard as unusual, bizarre or even threatening. Nevertheless, the interest protected by s 31 is not a statical one dependent on a counter-balancing of numbers, but a qualitative one based on respect for diversity."

21 Christian Education case par 30; Prince case par 128.

22 Par 139. 
strict scrutiny test has to be applied in the case of racial and gender discrimination. Although a person's right to religious freedom is one of the key ingredients of his/her human dignity ( $c f$ the Christian Education case), it is not absolute and may in certain circumstances be exceeded by the interest of the community or international obligations (cf the Prince case). 


\section{BIBLIOGRAPHY}

Carpenter, G 2001. Equality and non-discrimination in the new South African constitutional order. THRHR 64(3): 409-422.

Chaskalson, M, Kentridge, J, Klaaren, J, Marcus, G, Spitz, D \& Woolman, S (eds) 1998. Constitutional Law of South Africa. Revision Service 2. Cape Town: Juta.

Davis, D 1994. Equality and equal protection, in Van Wyk, D et al (eds) Rights and constitutionalism: the new South African legal order, 196-211. Cape Town: Juta.

De Waal, J, Currie, I \& Erasmus, G 2000. The Bill of Rights Handbook. Cape Town: Juta.

Du Plessis, M 2000. Doing damage to freedom of religion. Stellenbosch Law Review 2:295-305.

Freedman, W 2000. The right to religious liberty, the right to religious equality, and section 15(1) of the South African Constitution. Stellenbosch Law Review 1: 99-108.

Kok, A 2001. The Promotion of Equality and Prevention of Unfair Discrimination Act: why the controversy? Tydskrif vir Suid-Afrikaanse Reg 2: 204-310.

Malherbe, E F J 1998. Die grondwetlike beskerming van godsdiensvryheid. Tydskrif vir Suid-Afrikaanse Reg 3: 673-688.

Pienaar, G J 1999. Legal subjectivity and the juristic person. Potchefstroom: PU vir $\mathrm{CHO}$.

Pienaar, GJ 2002. The interaction between freedom of association, the free exercise of religion and equality. NG Teologiese Tydskrif dl 43 nrs 1 \& 2 266-275 
Rautenbach, I M 1995. General provisions of the South African Bill of Rights. Durban: Butterworths.

Rautenbach, I M \& Malherbe, E F J 1999. Staatsreg. 3de uitg, Durban: Butterworths.

Rautenbach, I M 2001. Die konstitusionele hof se riglyne vir die toepassing van die reg op gelykheid II. Tydskrif vir Suid-Afrikaanse Reg 2: 329-340.

Strydom, H A 1995. The private domain and the bill of rights. South African Public Law 10: $52-68$.

Van Wyk, D, Dugard, J, De Villiers, B \& Davis, D (eds) 1994. Rights and constitutionalism: the new South African order. Cape Town: Juta.

Woolman, S 1997. Out of order? Out of balance? The limitation clause of the final constitution. South African Journal of Human Rights 108-119.

Woolman, S 1998. Limitations, in Chaskalson, M et al (eds). Constitutional Law of South Africa, par 12 Cape Town: Juta.

Woolman, S, \& De Waal, J 1994. Freedom of association: the right to be we, in Van Wyk, D et al (eds) Rights and constitutionalism: the new South African legal order 338386. Cape Town: Juta. 